Article

\title{
Concurrent and Lagged Effects of Extreme Drought Induce Net Reduction in Vegetation Carbon Uptake on Tibetan Plateau
}

\author{
Chongchong Ye ${ }^{1,2}$, Jian Sun ${ }^{2, *}\left(\mathbb{0}\right.$, Miao Liu ${ }^{2}$, Junnan Xiong ${ }^{1}$, Ning Zong ${ }^{2}{ }^{-}$, Jian $\mathrm{Hu}^{3}{ }^{\circledR}$, \\ Yong Huang ${ }^{4}$, Xingwu Duan ${ }^{4}$ and Atsushi Tsunekawa ${ }^{5} \mathbb{D}$ \\ 1 School of Civil Engineering and Geomatics, Southwest Petroleum University, Chengdu 610500, China; \\ yechongchong@stu.swpu.edu.cn (C.Y.); xiongjn@swpu.edu.cn (J.X.) \\ 2 Synthesis Research Centre of Chinese Ecosystem Research Network, Institute of Geographic Sciences and \\ Natural Resources Research, Chinese Academy of Sciences, Beijing 100101, China; \\ liumiao@igsnrr.ac.cn (M.L.); zongning@igsnrr.ac.cn (N.Z.) \\ 3 Institute of Qinghai-Tibetan Plateau, Southwest Minzu University, Chengdu 610041, China; \\ jianhu@swun.edu.cn \\ 4 Institute of International Rivers and Eco-security, Yunnan University, Kunming 650091, China; \\ huangyong@ynu.edu.cn (Y.H.); xwduan@ynu.edu.cn (X.D.) \\ $5 \quad$ Arid Land Research Center, Tottori University, Tottori 6800001, Japan; tsunekawa@tottori-u.ac.jp \\ * Correspondence: sunjian@igsnrr.ac.cn; Tel.: +86-010-6488-9686
}

Received: 11 June 2020; Accepted: 20 July 2020; Published: 22 July 2020

Abstract: Climatic extremes have adverse concurrent and lagged effects on terrestrial carbon cycles. Here, a concurrent effect refers to the occurrence of a latent impact during climate extremes, and a lagged effect appears sometime thereafter. Nevertheless, the uncertainties of these extreme drought effects on net carbon uptake and the recovery processes of vegetation in different Tibetan Plateau (TP) ecosystems are poorly understood. In this study, we calculated the Standardised Precipitation-Evapotranspiration Index (SPEI) based on meteorological datasets with an improved spatial resolution, and we adopted the Carnegie-Ames-Stanford approach model to develop a net primary production (NPP) dataset based on multiple datasets across the TP during 1982-2015. On this basis, we quantised the net reduction in vegetation carbon uptake (NRVCU) on the TP, investigated the spatiotemporal variability of the NPP, NRVCU and SPEI, and analysed the NRVCUs that are caused by the concurrent and lagged effects of extreme drought and the recovery times in different ecosystems. According to our results, the Qaidam Basin and most forest regions possessed a significant trend towards drought during 1982-2015 (with Slope of SPEI $<0, P<0.05$ ), and the highest frequency of extreme drought events was principally distributed in the Qaidam Basin, with three to six events. The annual total net reduction in vegetation carbon uptake on the TP experienced a significant downward trend from 1982 to $2015\left(-0.0018 \pm 0.0002 \mathrm{PgC} \mathrm{year}^{-1}, P<0.001\right)$, which was negatively correlated with annual total precipitation and annual mean temperature $(P<0.05)$. In spatial scale, the NRVCU decrement was widely spread (approximately 55\% of grids) with $17.86 \%$ of the area displaying significant declining trends $(P<0.05)$, and the sharpest declining trend (Slope $\leq-2)$ was mainly concentrated in southeastern TP. For the alpine steppe and alpine meadow ecosystems, the concurrent and lagged effects of extreme drought induced a significant difference in NRVCU $(P<0.05)$, while forests presented the opposite results. The recovery time comparisons from extreme drought suggest that forests require more time (27.62\% of grids $\geq 6$ years) to recover their net carbon uptakes compared to grasslands. Therefore, our results emphasise that extreme drought events have stronger lagged effects on forests than on grasslands on the TP. The improved resilience of forests in coping with extreme drought should also be considered in future research. 
Keywords: extreme drought; net reduction in vegetation carbon uptake; concurrent and lagged effects; recovery time

\section{Introduction}

Approximately $25 \%$ of global anthropogenic $\mathrm{CO}_{2}$ emissions are counteracted by terrestrial ecosystems [1], but the terrestrial carbon cycle is easily affected by climate extremes. The increase in the frequency and intensity of climatic extremes predicted by global climate models in the 21st century [2] indicated that anthropogenic activities are changing the climate [3], which has an evident impact on the composition, structure and functions of terrestrial ecosystems and indirectly alters the terrestrial carbon balance [4-6]. Extreme drought is a typical extreme climatic event, and it has been reported in most regions globally, including East Asia [7], Europe [8,9], North America [10,11], Australia [12], and Amazonia [13]. It can cause tree mortality, decrease vegetation productivity, affect the ecosystem carbon balance, and even induce ecosystem degradation $[6,14-16]$. Therefore, it is vital to identify extreme drought events and assess their effects on the terrestrial carbon balance.

Previous studies have indicated that extreme drought events have concurrent and lagged effects on the terrestrial carbon balance by altering the respiration and carbon uptake rates for photosynthesis, and the coupling between them $[4,15]$. The concurrent effect can lead to a greater reduction in gross ecosystem productivity than that of ecosystem respiration $[4,15,17,18]$ (cause a net reduction in the carbon uptake of an ecosystem), as well as a reduced leaf area [15,19] (e.g., early leaf senescence, leaf shedding, and leaf expansion arrestment), and it is often related to a decrease in the $\mathrm{CO}_{2}$ assimilation rate due to the reductions in stomatal conductance, mesophyll thickness, and concentrations and activities of photosynthetic enzymes $[4,20,21]$. In addition to the concurrent effect, extreme drought events also exhibit lagged effects on the carbon cycle, such as the re-allocation of existing stored reserves being regulated to vindicate plant growth and defence $[4,22-24]$, an increase in vulnerability to pest and pathogen outbreaks $[6,15,25]$, and a higher risk of wild fires due to increased dry wood and defoliation following the extreme drought year $[4,6,15]$. These concurrent and lagged effects of extreme drought can directly or indirectly disturb ecosystem statuses or processes [3,26-28], change the responses of ecosystems to ambient environmental conditions $[3,29,30]$, and affect species compositions and their functional attributes $[3,31,32]$, thereby affecting the net carbon uptake of terrestrial ecosystems $[4,6,15]$. As the highest and most extensive plateau in the world, spanning from alpine tundra to tropic evergreen forest ecosystems, the Tibetan Plateau (TP) is considered to be the premonitory region for global climate change. Ecosystems are sensitive to climate variations on the TP and are easily destroyed by climatic extremes (e.g., extreme drought). It is worth noting that most studies are principally based on observations from single experimental sites, while the responses of ecosystems to concurrent and lagged effects of extreme drought have been ignored at broader spatial scales, especially on the TP. The TP is ideal as the study region for such research due to the sensitivity of its ecosystems to climate change, which can be utilised to capture sufficient information.

In recent years, many drought indices have been developed, including the Evaporative Stress Index [33], Reconnaissance Drought Index [34], Evaporative Demand Drought Index [35], Evapotranspiration Warning Index [36], Palmer Drought Severity Index [37], Standardised Precipitation Index [38], and Standardised Precipitation-Evapotranspiration Index (SPEI) [39], and the latter three drought indices are the most popular. The Palmer Drought Severity Index can simultaneously monitor wetness and dryness [37], but it has a strong calibration period influence and issues with spatial comparability that limit its application in other areas, with subjectivity between drought conditions and index values [39]. The Standardised Precipitation Index is widely accepted because of its sufficient comparability to various climate zones, benign spatial adaptability, multiple timescales, and simple structure, but its main criticism is that it only considers precipitation and ignores the influence of temperature and evapotranspiration [38-40]. The SPEI is a water balance model for precipitation 
and potential evapotranspiration, combining the Palmer Drought Severity Index (with changes in evaporation demand) and Standardised Precipitation Index (with sufficient spatial comparability and multitemporal nature) and considering drought sensitivity and global warming scenarios [39]. Currently, the meteorology sites on the TP, which are scattered because of the special terrain and complex ecosystems, together with the coarse spatial resolution of the Global SPEI database, have led to uncertainties in the TP drought characteristics; hence, drought monitoring data of improved resolution are urgently needed to capture drought characteristics on the TP.

In this study, we calculated the SPEI based on precipitation and temperature datasets with improved spatial resolutions, applied the Carnegie-Ames-Stanford approach (CASA) model to develop a net primary production (NPP) dataset across the TP during 1982-2015, and quantised the net reduction in vegetation carbon uptake (NRVCU) based on the NPP dataset. Our primary aims are to (1) investigate the spatiotemporal variabilities in the NPP, NRVCU, and SPEI; (2) identify the differences in NRVCU induced by the concurrent and lagged effects of extreme drought in forests, alpine steppe, and alpine meadow ecosystems; and (3) analyse the recovery time of vegetation net carbon uptake from extreme drought in different ecosystems.

\section{Materials and Methods}

\subsection{Study Area}

The TP (Figure 1) is composed of a series of magnificent mountains on all sides. Encompassing approximately $25 \%$ of China's mainland, the TP primarily includes the regions of north-western Sichuan, Qinghai, and Tibet. As 'Asia's water tower' [41], the Plateau possesses a typical thermal/moisture gradient from the southeast to northwest due to the elevation and monsoonal winds, and it includes a range of climate-sensitive vegetation along the climate change characteristics, from subtropical and tropical forests to alpine deserts. Specifically, the annual mean total precipitation increases from $16 \mathrm{~mm}$ in the northwest to $1764 \mathrm{~mm}$ in the southeast, as observed during the period of 1981-2011, with a corresponding variation gradient in the annual mean air temperature increasing from $-5.0^{\circ} \mathrm{C}$ in the northwest to $15.5^{\circ} \mathrm{C}$ in the southeast [42]. The climate type spatial pattern significantly affects vegetation productivity and is a pivotal element in determining the carbon cycle.

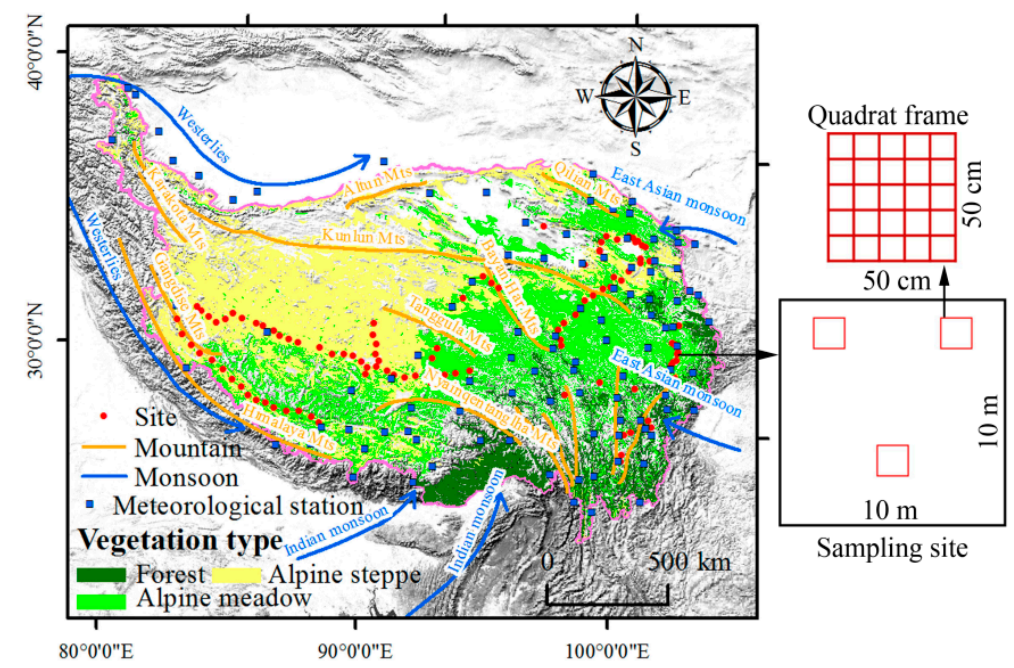

Figure 1. Locations of the sampling sites and meteorological stations on the Tibetan Plateau. The blue and orange lines denote monsoons and mountains, respectively. The colours represent the main vegetation types across the Tibetan Plateau, as depicted in the legend. 


\subsection{Data}

\subsubsection{Climate Datasets}

In this study, we used the monthly precipitation sum and monthly mean air temperature to calculate the 12-month SPEI. Anusplin 4.2 (Centre for Resource and Environmental Studies, Australian National University, Canberra) was utilised to process the spatial interpolations of precipitation and air temperature at a $1 / 12^{\circ}$ resolution for the period 1982-2015. Furthermore, the precipitation, air temperature, and solar radiation data were utilised to estimate NPP; however, few stations contain measurement of solar radiation on the TP. We used the daily air pressure, air temperature, relative humidity, and sunshine duration to estimate the monthly solar radiation, and the specific methods and details were based on those of previous studies [43,44]. The grid data of the monthly solar radiation were generated based on the Kriging interpolation method in ArcGIS 10.2 (ESRI, Inc., Redlands, CA, USA); the data resolution and period were consistent with those of the precipitation and air temperature data. These meteorological datasets were acquired from the China Meteorological Administration (http://cdc.cma.gov.cn), and the number of meteorological stations used in this study is 107 (Figure 1).

\subsubsection{Aboveground Site Biomasses}

During the summer (from the end of July to mid-August) in 2015, we clipped the aboveground parts of plants at 115 sampling sites on the TP (Figure 1). Of the sampling sites, 55 sites were from alpine meadow, 55 sites were from alpine steppe, and 5 sites were from alpine desert steppe ecosystems. At each site $(10 \mathrm{~m} \times 10 \mathrm{~m})$, we set up three $50 \mathrm{~cm} \times 50 \mathrm{~cm}$ paired plots to harvest aboveground plant samples. To obtain a constant mass for the aboveground biomass in the laboratory, the aboveground parts of the plants were oven-dried at $65{ }^{\circ} \mathrm{C}$ after sun-drying them in a field and weighing them to the nearest $0.1 \mathrm{~g}$.

\subsubsection{Satellite-Derived Datasets}

Normalised difference vegetation index $\left(\mathrm{NDVI}_{3 \mathrm{~g}}, 1982-2015\right)$ data were used in this study to estimate the gridded TP NPP at a $1 / 12^{\circ} \times 1 / 12^{\circ}$ resolution. The data were acquired from the Advanced Very High Resolution Radiometer observation instruments created by the Global Inventory Modeling and Mapping Studies group [45]. In addition, one satellite and atmospheric data-driven global annual NPP product, with a $0.05^{\circ}$ spatial resolution for the period 2000 to 2015, was obtained from the Numerical Terradynamic Simulation Group, University of Montana (http://files.ntsg.umt.edu/ data/NTSG_Products/MOD17/GeoTIFF/MOD17A3/GeoTIFF_30arcsec/) and used as a comparison for the NPP produced in this study. Here, the Moderate Resolution Imaging Spectroradiometer (MODIS)-derived NPP product was resampled (via the bilinear interpolation method) in a $1 / 12^{\circ} \times 1 / 12^{\circ}$ grid to match the estimated NPP.

\subsubsection{Soil Characteristics Database}

To investigate the effects of soil physical and chemical attributes on the vegetation net carbon uptake, we used the soil characteristics database including alkali-hydrolysable $\mathrm{N}(\mathrm{mg} / \mathrm{kg})$, available $\mathrm{P}(\mathrm{mg} / \mathrm{kg})$, available $\mathrm{K}(\mathrm{mg} / \mathrm{kg})$, cation exchange capacity (me/100 g), soil organic matter $(\mathrm{g} / 100 \mathrm{~g}), \mathrm{pH}\left(\mathrm{H}_{2} \mathrm{O}\right)$, total $\mathrm{N}$ $(\mathrm{g} / 100 \mathrm{~g})$, and total $\mathrm{P}(\mathrm{g} / 100 \mathrm{~g})$, which was developed for a land surface model that included eight vertical variation layers with a 30 arc seconds resolution and was produced by the Land-Atmosphere Interaction Research Group at Sun Yat-sen University (http://globalchange.bnu.edu.cn/research/soil2). In this study, we used the first layer $(0-0.045 \mathrm{~m})$. The soil moisture data were obtained from the National Earth System Science Data Center (http://www.geodata.cn/data/datadetails.html? dataguid=5864857\&docId=1865) at a $5-\mathrm{km}$ resolution, and this data was rebuilt by downscaling based on soil moisture data from the European Space Agency Climate Change Initiative. 


\subsubsection{Vegetation Distribution Map}

The TP vegetation distribution map used in this study was extracted from the 1:1,000,000 China vegetation map, which was obtained from the Resource and Environment Data Cloud Platform (http://www.resdc.cn/data.aspx?DATAID=122) and reclassified into nine categories: grassland, shrubland, cropland, evergreen needle-leaf forest, deciduous needle-leaf forest, evergreen broad leaf forest, deciduous broadleaf forest, mixed forest, and other (water bodies, snow and ice, etc.). Furthermore, the spatial patterns of these major vegetation types (alpine meadow, alpine steppe, and forests) are displayed in Figure 1.

\subsection{Methods}

\subsubsection{Drought Indices}

The SPEI is a standardised drought index that represents a simple climatic water balance (precipitation and potential evapotranspiration) with comparable results for multifarious climate regimes [40]. Furthermore, the SPEI possesses a flexible timescale and allows the monitoring of different drought types including hydrological, agricultural, and meteorological droughts [46]. Hence, the SPEI is applicable for TP drought monitoring. Unfortunately, there is the disadvantage that the SPEI requires at least 30 years of data to be employed [47], whereas some developing countries do not yet possesses $>30$ years of ground observations. Additionally, the resolution of the existing SPEI dataset (provided by the Global SPEI database at a $0.5^{\circ}$ resolution) cannot satisfy the requirements for regional research. In this study, precipitation and potential evapotranspiration datasets from 1982 to 2015 were used to calculate the 12-month SPEI, and the detailed potential evapotranspiration calculation was based on previous studies using the air temperature data [39,48]. Here, we intend to explore the concurrent and lagged effects of extreme drought on the vegetation net carbon uptake. Therefore, we selected a 12-month time-scale because long-term extreme drought has a significant lagged effect on plants, and the potential evapotranspiration can be better captured through long-term observation [39]. The SPEI drought severity categories are displayed in Table 1, and the comparison between the existing and calculating SPEI is supplemented in Figure S1.

Table 1. Drought severity categories for the Standardised Precipitation-Evapotranspiration Index (SPEI).

\begin{tabular}{ll}
\hline Description & SPEI Value \\
\hline Non-drought & $>0$ \\
Mild drought & $-1 \sim 0$ \\
Moderate drought & $-1.5 \sim-1$ \\
Severe drought & $-2 \sim-1.5$ \\
Extreme drought & $<-2$ \\
\hline
\end{tabular}

\subsubsection{NPP Data Reconstruction and Accuracy Validation}

In this study, the CASA model was used to estimate the gridded TP NPP at a $1 / 12^{\circ} \times 1 / 12^{\circ}$ resolution [49-51]. The NPP is the product of absorbed photosynthesis active radiation (APAR) by the green vegetation and actual light use efficiency $(\varepsilon)$.

$$
N P P(x, t)=A P A R(x, t) \times \varepsilon(x, t)
$$

where $\mathrm{NPP}(x, t)\left(\mathrm{gC} \mathrm{m}^{-2}\right)$ denotes the vegetation NPP at pixel $x$ at time $t$, and the $A P A R(x, t)\left(\mathrm{MJ} \mathrm{m}^{-2}\right)$ and $\varepsilon(x, t)\left(\mathrm{gC} \mathrm{MJ}^{-1}\right)$ represent the APAR by the green vegetation and actual light use efficiency, respectively. The specific and detailed parameter calculation method was discussed in previous studies [50,52]. The validation can be executed either by comparing the estimated NPP with the gauged data NPP or with other modelling results. Here, the gauged NPP is obtained from the conversion of aboveground biomass in 2015: (1) the belowground biomass is calculated based on the ratio of belowground to 
aboveground biomass for alpine meadow (7.92), alpine steppe (4.25), and alpine desert steppe (7.89) ecosystems [53]; (2) the sum of belowground and aboveground biomass is the total biomass, which is multiplied by a coefficient of 0.45 to get gauged NPP with carbon unit [54]. To ensure the availability of the estimated NPP, several validation statistical indices were used between the gauged and estimated NPP (or MODIS-derived NPP) in 2015, and the specific formulas derived from previous research [55].

\subsubsection{The Quantification of NRVCU}

Drought events have a stronger inhibition on gross photosynthesis than total ecosystem respiration, which leads to an NRVCU. Here, the NPP was applied to denote the vegetation net carbon uptake, and the multi-year average of NPP was used as the normal net carbon uptake level of vegetation. Then, the multi-year average NPP was subtracted from the annual NPP in each grid, the negative value is the NRVCU [6], the zero and positive value denote no NRVCU and are assigned to 0 . Furthermore, the net reduction rate of vegetation carbon uptake (NRRVCU) is captured by the ratio of NRVCU to NPP.

\subsubsection{Grid Trends, Interannual Variabilities, and Anomalies of NPP, NRVCU, and SPEI}

The temporal trends (from 1982 to 2015) of NPP, NRVCU, and SPEI in each grid are computed using a linear least square regression method according to that of previous research [56]. Additionally, the standard deviations of the annual NPP and NRVCU during the studied period were calculated for each grid using the methodology in Anav et al. (2015) [57]. The counts of extreme drought (SPEI <-2) for each pixel during the study period were processed based on ArcGIS 10.2 software. The interannual variabilities of NPP, NRVCU, and SPEI for each grid were based on the following equations from Ahlström et al. (2015) [58,59]:

$$
\begin{gathered}
f_{g}=\frac{\sum_{t} \frac{a_{g t}\left|A_{t}\right|}{A_{t}}}{\sum_{t}\left|A_{t}\right|} \\
A_{t}=\sum_{g} a_{g t}
\end{gathered}
$$

where $a_{g t}$ denotes the NPP (or NRVCU or SPEI) anomaly (long-term deviation) for the grid $g$ at time $t$, and $A_{t}$ denotes the total anomaly of NPP (or NRVCU or SPEI) in the TP. Here, $f_{g}$ is the averaged relative value $a_{g t} / A_{t}$ for grid $g$ weighted by the absolute TP NPP (or NRVCU or SPEI) total anomaly $\left|A_{t}\right|$, and it includes both the sign and extent of the local contribution with a range from -1 to 1 .

\subsubsection{The Response of Vegetation Net Carbon Uptake to Extreme Drought}

Extreme drought complexly impacts the vegetation net carbon uptake; thus, an understanding of the probable mechanisms and processes involved in extreme effects is crucial. As Figure 2 illustrates, the vegetation net carbon uptake decreases during the extreme drought period (e.g., reduced productivity or increased mortality), which is called the concurrent effect. However, there can be no suppression in a region with strong drought resilience (such as this region with abundant soil water and nutrient substance). Afterwards, the vegetation net carbon uptake gradually recovers as precipitation returns over time. The duration of the recovery process for vegetation net carbon uptake is the recovery time ( $\Delta \mathrm{t}$ in Figure 2). The damage magnitude caused by extreme drought determines the disparate recovery time and lagged regrowth. The NRVCU over the time following the year of an extreme drought was primarily due to the lagged effect (e.g., reduced bud development). In this study, the difference in NRVCU induced by the concurrent (during extreme drought period) and lagged effects (in the year following the extreme drought) and the recovery time were explored in alpine steppe, forest, and alpine meadow ecosystems, and the selected area exhibited no extreme drought events in the 10 years before/after the extreme drought year. 


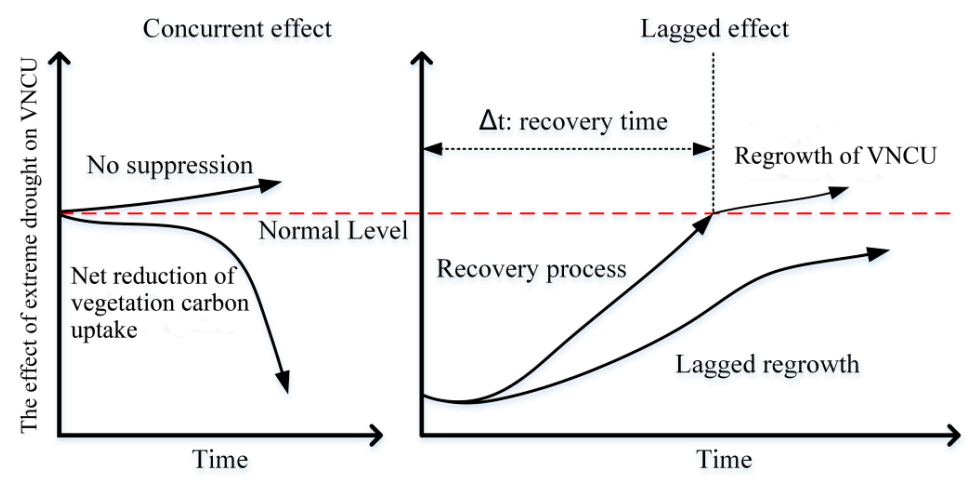

Figure 2. Schematic diagram about the response of vegetation net carbon uptake (VNCU) to extreme drought [4]. The red dotted line indicates the normal level of vegetation net carbon uptake.

\section{Results}

\subsection{Spatiotemporal Patterns of NPP, NRVCU, and SPEI on the TP}

In this study, the regional NPP dataset was developed during 1982-2015, and its reliability is apparent. Validation statistical indices for the dataset were calculated between the gauged and estimated (or MODIS-derived) NPP. The mean error (155.72), relative bias (-48.77), Nash-Sutcliffe coefficient efficiency (0.24), root mean square error (278.01), and correlation coefficient $(0.80)$ of the estimated NPP have a better performance than that of the MODIS-derived NPP (-205.26, 64.29, 0.03, 314.09, and 0.74) when compared to the gauged NPP (Figure 3a). According to the regional NPP dataset, the NPP demonstrates a descendant gradient in the southeast-northwest direction, with the lowest value $\left(<100 \mathrm{gC} \mathrm{m}^{-2}\right.$ year $\left.^{-1}\right)$ in the northwest and the highest value $\left(>1400 \mathrm{gC} \mathrm{m}^{-2} \mathrm{year}^{-1}\right)$ in the southeast (Figure 3b). The NRVCU gradient variation is consistent with that of NPP, with the highest values (>90 $\mathrm{gC} \mathrm{m}^{-2}$ year $^{-1}$ ) principally occurring in the southeast and lowest values $\left(<10 \mathrm{gC} \mathrm{m}^{-2} \mathrm{year}^{-1}\right)$ being primarily distributed in the northwest (Figure 3c).
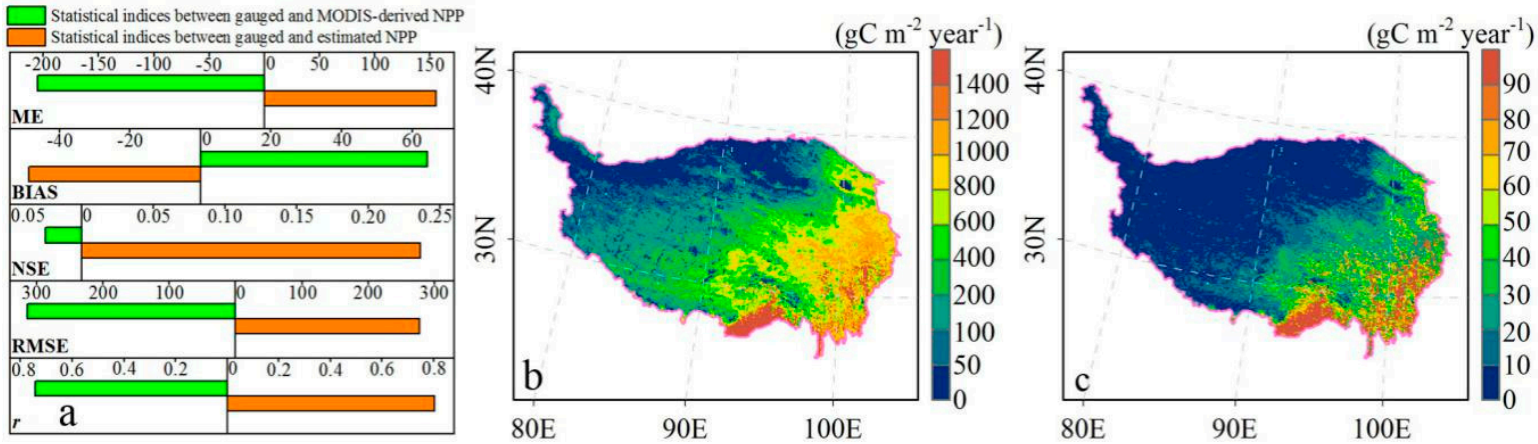

Figure 3. (a) The validation statistical indices (ME: mean error, BIAS: relative bias, NSE: Nash-Sutcliffe coefficient efficiency, RMSE: root mean square error, and $r$ : correlation coefficient) between the gauged and estimated (or MODIS-derived) net primary production (NPP). (b) The spatial pattern of the multi-year average NPP on the Tibetan Plateau during 1982-2015. (c) The spatial pattern of the multi-year average of net reduction in vegetation carbon uptake across Tibetan Plateau during 1982-2015.

During the study period, the annual total net reduction in vegetation carbon uptake of the TP decreased from $0.13 \mathrm{PgC}$ in 1982 to $0.05 \mathrm{PgC}$ in 2015, with a significant downtrend of $-0.0018 \pm 0.0002 \operatorname{PgC} \operatorname{year}^{-1}(P<0.001$, Figure 4a). Inversely, the annual total precipitation and annual mean temperature significantly increased at a rate of $1.0952 \pm 0.3577 \mathrm{~mm}^{-1} \mathrm{mear}^{-1}(P=0.004$, Figure $4 \mathrm{c})$ and $0.0546 \pm 0.0069^{\circ} \mathrm{C}_{\text {year }^{-1}}(P<0.001$, Figure $4 \mathrm{~d})$, respectively. During the studied period, the largest extreme drought area occurred in $2009\left(2.8 \times 10^{5} \mathrm{~km}^{2}\right.$, Figure 4b), whereas in 1996, 2005 and 2012, there were no extreme drought events on the TP. The interannual variation of the annual total net reduction 
in vegetation carbon uptake was negatively correlated with the annual total precipitation $\left(R^{2}=0.19\right.$, $P=0.006$, Figure $4 \mathrm{e})$ and annual mean temperature $\left(R^{2}=0.60, P<0.001\right.$, Figure $\left.4 \mathrm{f}\right)$. Furthermore, precipitation and temperature demonstrated a significant positive correlation $\left(R^{2}=0.16, P=0.01\right.$, Figure 4g).
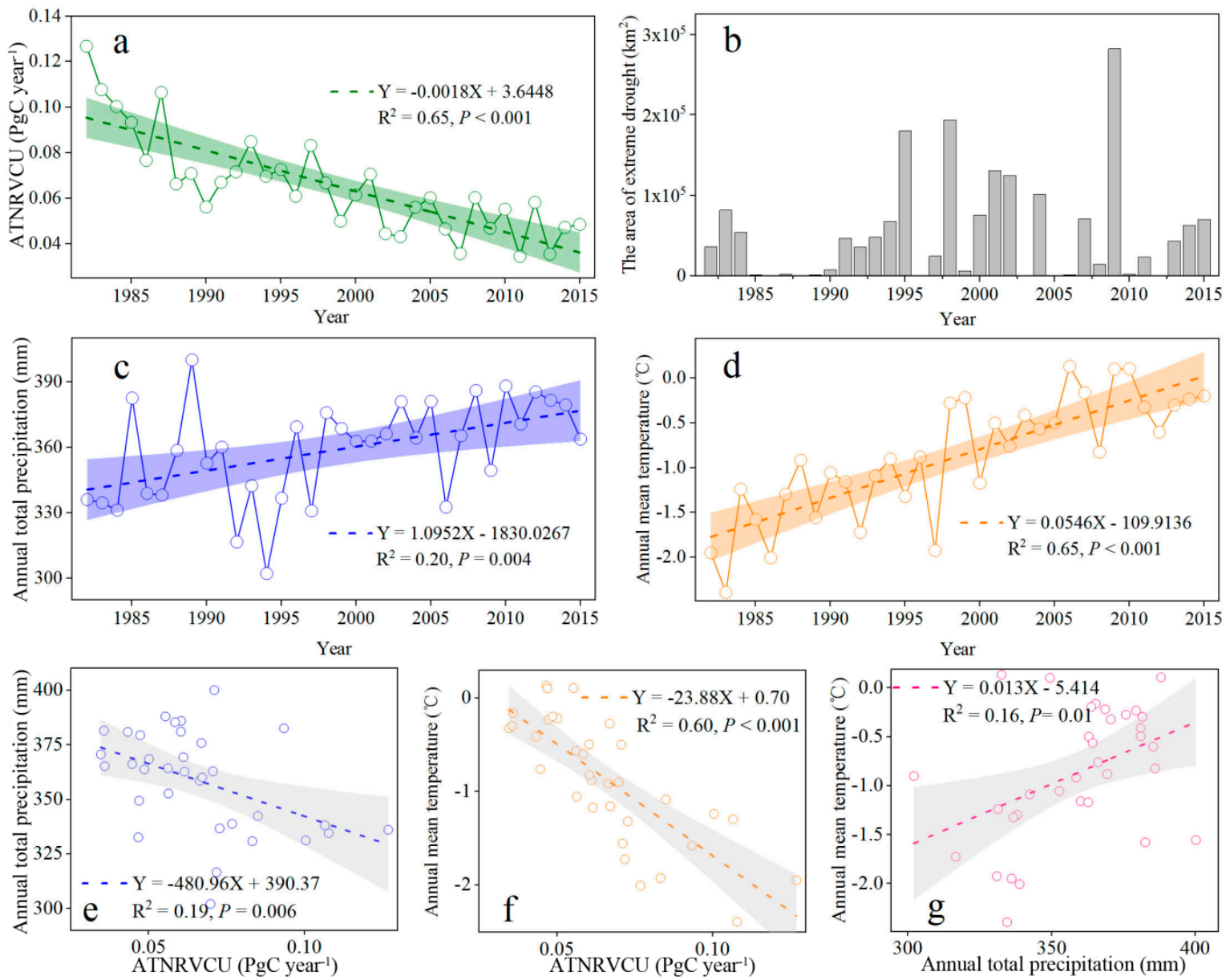

Figure 4. Interannual change in (a) the annual total net reduction in vegetation carbon uptake (ATNRVCU) during 1982-2015, (b) annual area of extreme drought, (c) annual total precipitation, and (d) annual mean temperature. The correlation analysis between (e) ATNRVCU and annual total precipitation, (f) ATNRVCU and annual mean temperature, and (g) annual total precipitation and annual mean temperature.

The NPP temporal trend, interannual variability (IAV), and standard deviation demonstrated a heterogeneous geographical distribution for the 1982-2015 period. Most of the area (70.86\%) presented an increasing trend, and approximately $35 \%$ of the study region displayed a significantly increasing trend $(P<0.05$, Figure 5a), with a high positive trend mainly in the southeast and low negative value chiefly in the central region. In addition, the alpine steppe ecosystem mainly demonstrated the positive NPP trend (75.7\%, Slope $>0$; Figures 5a and S2a). The IAV of most regions $(91.03 \%$, IAV > 0) was consistent with the TP NPP, with the maximum mainly distributed in the forest ecosystem (the average value is $0.007 \%$; Figures $5 \mathrm{~b}$ and S2b). Similarly, high values $\left(>180 \mathrm{gC} \mathrm{m}^{-2}\right.$ year $\left.^{-1}\right)$ of the NPP standard deviation principally occurred in the southeast, with the lowest values $\left(<20 \mathrm{gC} \mathrm{m}^{-2}\right.$ year $\left.^{-1}\right)$ occurring in the northwest (Figure 5c). We also found that approximately $55 \%$ of the NRVCU grids experienced a downward trend, and a significant region $(P<0.05)$ accounted for $17.86 \%$, and the sharpest declining trend (Slope $\leq-2$ ) was primarily concentrated in the southeast (Figure $5 \mathrm{~d}$ ). The alpine meadow and alpine steppe ecosystems appeared to contribute the most to the IAV of the NRVCU $(45.66 \%$ and 
$15.89 \%$, respectively; Figure S2e), which was predominately distributed in the eastern and central parts of the study area (Figure 5e). The NRVCU standard deviation exhibited the same pattern as that of the NPP (Figure 5f). Furthermore, we also measured the SPEI temporal trend, which exhibited a significant trend towards drought that primarily occurred in the Qaidam Basin and most forest ecosystems $(P<0.05$, Slope $<0$, Figure $5 \mathrm{~g})$. Most of the study region $(87.92 \%)$ experienced a consistent IAV in the TP SPEI (positive value in Figure $5 \mathrm{~h}$ ). Of the extreme drought events in the TP (SPEI $<-2$ ), the Qaidam Basin exhibited the highest event frequency (count $\geq 3$, Figure 5i).

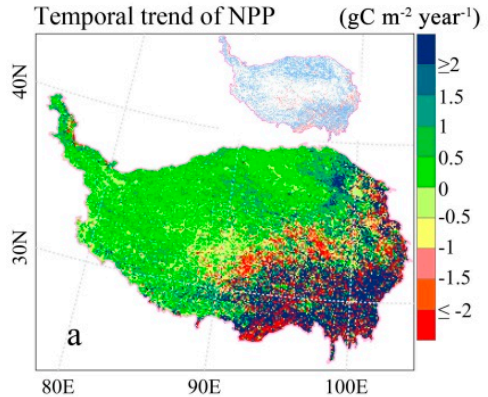

Temporal trend of NRVCU $\quad\left(\mathrm{gC} \mathrm{m}^{-2}\right.$ year $\left.^{-1}\right)$

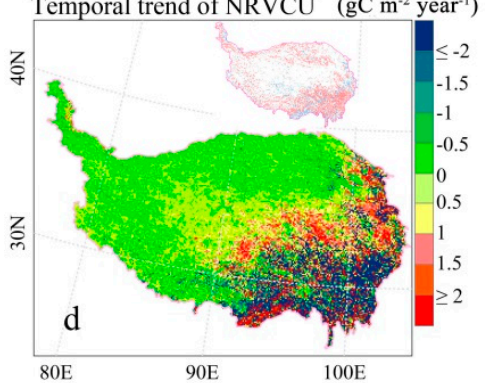

Temporal trend of SPEI

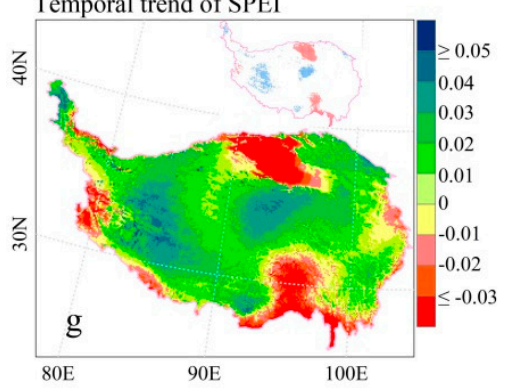

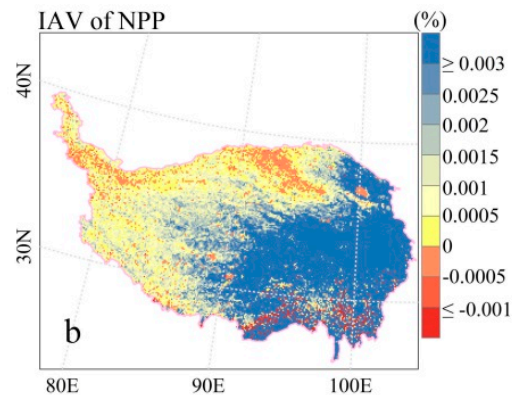
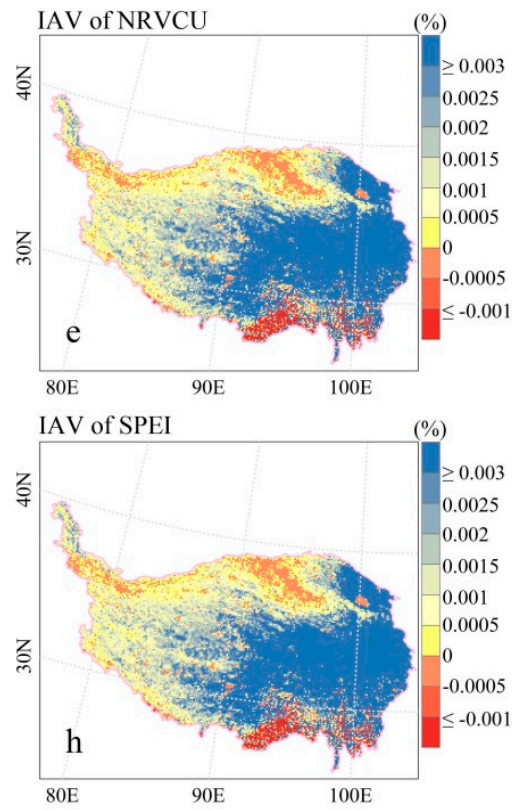

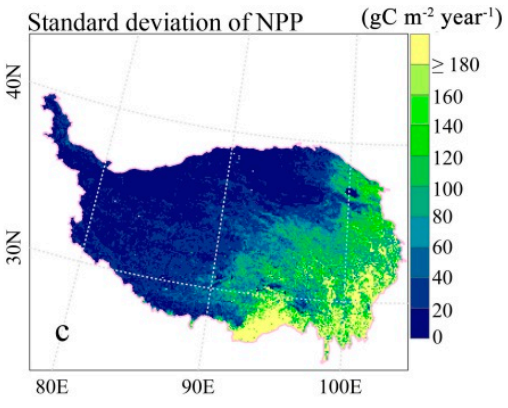

Standard deviation of NRVCU $\left(\mathrm{gC} \mathrm{m}^{-2}\right.$ year $\left.^{-1}\right)$
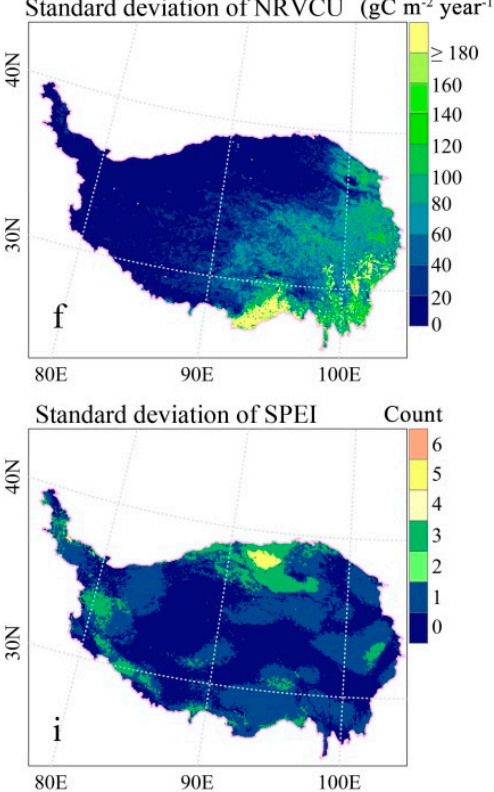

Figure 5. Spatial patterns of $(\mathbf{a}, \mathbf{d}, \mathbf{g})$ temporal trends; (b,e,h) interannual variability (IAV); and $(\mathbf{c}, \mathbf{f})$ standard deviations of the net primary production (NPP), net reduction in vegetation carbon uptake (NRVCU) and Standardised Precipitation-Evapotranspiration Index (SPEI) during 1982-2015. (i) Count of extreme drought events at the grid level across the Tibetan Plateau during 1982-2015. Insets in the upper right for panels $(\mathbf{a}, \mathbf{d}, \mathbf{g})$ denote the significant linear trends $(P<0.05)$ at the grid scale during the study period; red and blue points represent the decrease and increase tendencies, respectively.

\subsection{The Concurrent and Lagged Effects of Extreme Drought Leading to an NRVCU}

We further examined the NRVCU induced by the concurrent and lagged effects in the alpine steppe, alpine meadow, and forest ecosystems. A dominant influencing difference was discovered in the alpine steppe and alpine meadow ecosystems $(P<0.05)$. Of the grids, $83.01 \%$ and $55.43 \%$ experienced an NRVCU that was induced by the concurrent effect in the alpine steppe and alpine meadow ecosystems, respectively (Figure 6a,b). However, an NRVCU caused by the lagged effect only accounted for $8.25 \%$ and $12.90 \%$ of grids in the alpine steppe and alpine meadow ecosystems, respectively (Figure $6 \mathrm{a}, \mathrm{b}$ ). For the concurrent and lagged effects in forests, there was no significant 
difference $(P>0.05)$ in the NRVCU. Approximately $67 \%$ of grids experienced an NRVCU caused by the concurrent effect. Similarly, the lagged effect led to an NRVCU for $64.03 \%$ of the grids (Figure $6 c$ ). Furthermore, the NRRVCU possessed the same characteristics as those of the NRVCU (Figure 6d-f).
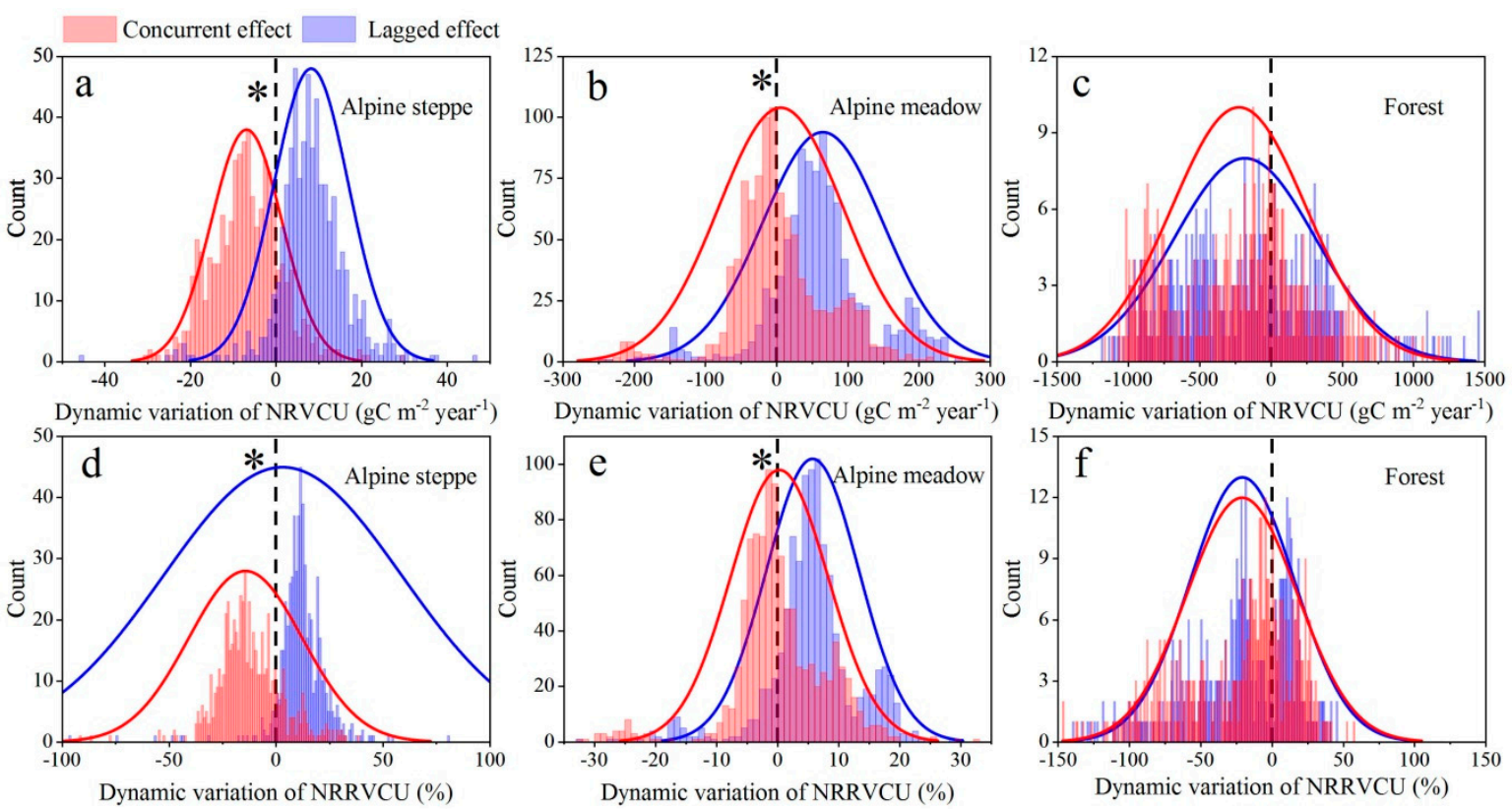

Figure 6. The net reduction in vegetation carbon uptake (NRVCU) caused by the concurrent and lagged effects of extreme drought for (a) alpine steppe, (b) alpine meadow, and (c) forest ecosystems. $(\mathbf{d}, \mathbf{e}, \mathbf{f})$ denote the net reduction rate of vegetation carbon uptake (NRRVCU) of alpine steppe, alpine meadow, and forest ecosystems, respectively. Red and blue bars (lines) represent the concurrent and lagged effects, respectively. The asterisk $\left.{ }^{*}\right)$ indicates a significant difference between the concurrent and lagged effects at $P<0.05$.

\subsection{The Vegetation Net Carbon Uptake Recovery from Extreme Drought}

After the extreme drought event, the vegetation net carbon uptake gradually recovered, with different recovery times across vegetation types (Figure 7). The alpine meadow ecosystem possessed a higher proportion of grids (44.57\%) with no suppression when faced with extreme drought, followed by forests $(32.76 \%)$ and alpine steppe $(16.99 \%)$. The alpine steppe ecosystem's net carbon uptake recovered faster than the other two types (alpine meadows and forests), with more than $75 \%$ of grids recovering from the extreme drought within 1 year (Figure 7a). Compared to the alpine steppe ecosystem, the alpine meadow required a longer time period to recover the vegetation net carbon uptake (Figure 7b), with more than $50 \%$ of grids returning to normal levels within 4 years. Regarding forests, only $39.61 \%$ of grids recovered from the extreme drought within 5 years (Figure $7 \mathrm{c}$ ), and more than $25 \%$ of grids require at least 6 years to recover. 


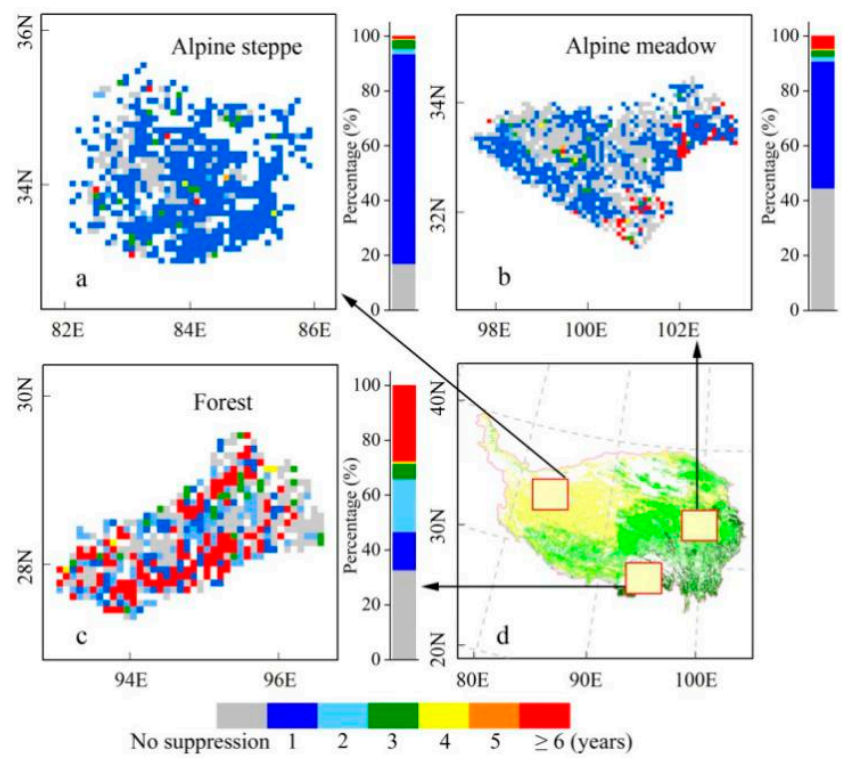

Figure 7. The recovery time of net reduction in vegetation carbon uptake and fraction of recovery time in (a) alpine steppe, (b) alpine meadow, (c) forest ecosystems, and (d) The Location of selected area on the Tibetan Plateau.

\section{Discussion}

\subsection{NRVCU Spatiotemporal Patterns}

The interannual changes in annual total net reduction in vegetation carbon uptake experienced a significant downward trend during the 1982-2015 period (Slope $<0, P<0.001$, Figure 4a). A correlation analysis demonstrated that the NRVCU gradually decreased as the annual total precipitation and annual mean temperature increased (Figure $4 \mathrm{c}, \mathrm{d}$ ). The favourable water and heat conditions, such as abundant soil moisture and mineral elements that are salutary for the vegetation net carbon uptake, provided important resources for vegetation growth [4,60-64]. The soil water supply determines whether the vegetation photosynthesis operates normally when the $\mathrm{CO}_{2}$ concentration and light are sufficient $[4,21,60]$; thus, increased precipitation played a crucial role in ameliorating the vegetation net carbon uptake (Figures 4e and S3a). Additionally, soil water is an indispensable intermediary that guarantees the transportation of nutrients [60], which seems to support our findings regarding the NRVCU on the TP (Figure 4a). In addition to water, temperature is another climate variable affecting the vegetation net carbon uptake (Figures $4 \mathrm{f}$ and S3b). The increase in temperature facilitates vegetation growth without encountering water limitations [59]. In addition, climate warming can stimulate the enzymatic activities of photosynthesis $[60,65]$, with an evident promotion in the vegetation net carbon uptake. The increase in soil respiration as the climate warms is suitable for plant productivity due to the acceleration of mineralisation and the decomposition of organic matter $[60,66,67]$, which explained why the NRVCU gradually declined (Figure 4a). Finally, an increased temperature may extend the length of the vegetative growing season $[60,68]$, which is responsible for an increase in plant productivity, thereby restraining the NRVCU. In general, although a few studies have shown a downward trend of precipitation at individual meteorological station [69], the general improvements in the water and heat conditions visibly enhanced the capacity of the vegetation net carbon uptake on the TP (Figure 4a,c-g, Figure S3a-c).

The multi-year (1982-2015) average NRVCU on the TP presented a distinct geographical pattern (Figure 3c), with a gradient variation from the southeast $\left(>90 \mathrm{gC} \mathrm{m}^{-2}\right.$ year $\left.^{-1}\right)$ to northwest $\left(<10 \mathrm{gC} \mathrm{m}^{-2}\right.$ year $\left.^{-1}\right)$ that was highly consistent with the multi-year average NPP (Figure $3 \mathrm{~b}$ ). The variation pattern potentially reflects the climate variability affecting plant productivity (Figures S4 and S5). The TP climate is primarily controlled by the East Asia monsoon [59,70] because the 
Himalaya mountains obstruct the Indian monsoon, together with the route of westerlies (Figure 1), which determined the gradually reduced gradient of precipitation (Figure S4a) from the southeast to northwest and thereby dominated the plant productivity patterns related to the climate gradient (Figure 3b). In this context, the vegetation net carbon uptake may possess a greater reduction in the southeastern TP when normal ecosystem functioning is restrained by external factors, which seems to support our findings (Figure 3c). Similarly, the finding that vegetation growth is easily affected by the TP climate is also supported by previous studies [70,71]. The tendency towards drought (Slope $<0$ of SPEI, Figure 5g) is a determinant that led to the greater NRVCU in forests than in other ecosystem types (Figure 3c), while the same SPEI trend (Slope $<0$, Figure 5g) in the Qaidam Basin did not induce the large NRVCU that can be attributed to lower plant productivity in this alpine desert region (Figures 1 and $3 b$ ). In terms of arid regions, plants in the northwestern TP possessed a lower photosynthesis rate, leaf area, species diversity, nitrogen content, growth rate, and the growing season length, which resulted in a weak net carbon uptake capacity of vegetation [72-74]. However, plant is equipped with an adaptive ability to grow in poor environmental conditions (Figures S4, S6, and S7); thus, it experiences a lower NRVCU (Figure 3c) than that in a nutrient-rich environment (e.g., southeastern TP) when a drought occurs. Furthermore, the NRVCU variation trends presented an increase in forests and eastern regions but a decrease in the northwestern and southeastern TP (Figure 5d); this was supported by the SPEI variation trends (Figure 5g). The IAV of NRVCU on the TP was primarily dominated by alpine meadow and alpine steppe ecosystems (Figures 5e and S2e), suggesting that the pattern of precipitation and temperature variability are driving the NRVCU for alpine steppe and alpine meadow ecosystems, respectively (Figures S4a,b,d,e and S5a-d).

\subsection{Response of the Vegetation Net Carbon Uptake to Extreme Drought}

The ecosystems experienced different negative feedbacks to the extreme drought event. We found that the differences in NRVCU (and NRRVCU) between the concurrent and lagged effects induced by extreme drought were significant $(P<0.05)$ for the alpine steppe and meadow ecosystems, while forests exhibited the opposite trend (Figure 6). Grasslands generally have a simpler structure and fewer species than forests [6]. The aboveground portion of the ecosystem is more prone to blights when encountering extreme drought [6,75-77], but it can quickly recover as precipitation occurs and soil moisture replenishes [6,76,78]. There are also many annual plants in grasslands [79] that can typically develop without nutrient restrictions in the year following an extreme drought. These characteristics determined the lower NRVCU for the lagged effects and thus the significant reduction difference for vegetation net carbon uptake between the concurrent and lagged effects caused by extreme drought (Figure $6 \mathrm{a}, \mathrm{b}, \mathrm{d}, \mathrm{e})$. In comparison, the forests possessed a more complex structure and higher productivity [80], which increased their resilience to extreme drought because they can capture deeper underground water $[4,81]$. Although forests have a more resilient system than grasslands, their mortality can significantly increase when an extreme drought imposes stress that is greater than the acceptable threshold [4], thereby inducing a serious lagged effect after the extreme drought year. Therefore, the vegetation net carbon uptake may not quickly recover to the previous level due to forest dieback [4], fire disturbances [6], pest and pathogen breakouts [82], etc., which may explain why the discrepancy in NRVCU between the concurrent and lagged effects induced by extreme drought was inconspicuous $(P>0.05)$ in forests (Figure $6 \mathrm{c}, \mathrm{f})$.

Not only do the difference in NRVCU (and NRRVCU) between the concurrent and lagged effects induced by extreme drought but also the recovery time distinctly differed in alpine steppe, alpine meadow, and forest ecosystems, highlighting ecosystem characteristics related to the soil moisture [60], soil physical and chemical properties [4], nutrients [83], light, non-structural carbohydrates [6], etc. We found that the alpine meadow ecosystem possessed a greater proportion $(44.57 \%)$ of the study region that exhibited no suppression during the extreme drought year (Figures 6 and 7), followed by the forest $(32.76 \%)$ and alpine steppe (16.99\%) ecosystems. The alpine meadow ecosystem is closely connected with the prevailing grassland one where climatic conditions are unfit for woody plants to 
exist and with the comparatively higher turnover rates than forests [4] that can be more resilient to extreme drought without nutrient restrictions (Figures S6 and S7). For the alpine steppe ecosystem in arid regions (e.g., the northwestern TP), vegetation encountered an insufficient nutrition and soil moisture supply [84] and the vegetation net carbon uptake was easily disturbed by the extreme drought, but it quickly returned to the previous level within 1 year (more than $75 \%$ of grids, Figure $7 a$ ) due to the its adaptive capacity for drought [4]. When comparing the recovery times of forests and grasslands, we found that forests required a longer time to recover their net carbon uptakes, and more than $25 \%$ of grids experienced the lagged maintain (recovery time $\geq 6$ years, Figure $7 \mathrm{c}$ ). The longer recovery time of vegetation net carbon uptake for forests is primarily attributed to the lagged effect caused by extreme drought; for example, the forest dieback during the extreme drought year led to decreased photosynthesis and lagged carbon emissions following the extreme drought $[3,4,13]$. Forests were also more assaulted by pest and pathogen breakouts than grasslands were [4,82], which severely restrained vegetation growth and caused an NRVCU [6]. In addition, the extreme drought altered carbon allocation, with more carbon being assigned to roots (or leaves) than to bole growth [82], which led to growth decline. The lagged effect of extreme drought can also cause the remnants of xylem cavitation that impair the water transport process and thereby restrict normal net carbon uptake rates of vegetation [82]. These lagged effects are related to plant growth, and they extend the recovery time of vegetation net carbon uptake.

\subsection{Importance and Uncertainties}

In our study, with the improvement in spatial resolution, the SPEI was considered to be the water balance between precipitation and potential evapotranspiration, and it measured the drought sensitivity magnitude across the TP during 1982-2015, which captured a credible drought spatiotemporal variability when compared with the sparse and uneven station distribution and insufficient ground-based observations $[40,85,86]$. For the SPEI quantisation process, the potential evapotranspiration was introduced to calculate the SPEI, and global warming scenarios were considered [39]. Additionally, the complicated terrain also affected the climate, especially the precipitation and temperature, which are indispensable datasets for calculating the SPEI. Fortunately, the Anusplin 4.2 was used to process their spatial interpolations related to terrain. Moreover, we adopted a light use efficiency model (i.e., the CASA model) to estimate NPP across the TP during 1982-2015, which can decrease uncertainties owing to extrapolations and interpolations and to mirror the vegetation growth statuses and ecosystem function changes and health conditions as the interference of the external environment [87]. Based on the NPP dataset, the NRVCU was quantified at the spatiotemporal scale, which revealed the net carbon flux variations of vegetation on the TP, with a reliable interannual variation being related to climate change. Finally, the difference between the concurrent and lagged effects induced by extreme drought on the NRVCU highlighted the different response mechanisms of vegetation both during and after the extreme drought events, which is salutary for future studies regarding the effect of climate change on vegetation net carbon uptake.

Despite progress being made via this study, large uncertainties remain. The SPEI calculation requires a long-term meteorological dataset of at least 30 years, and the optimal duration is 50-60 years [40]. We adopted a duration of 34 years from 1982 to 2015, which is shorter than the optimal duration and may lead to decreased accuracy. The SPEI possesses multiple timescale characteristics, and this study employed a 12-month timescale because the lagged effect requires a long-term interference of extreme drought and potential evapotranspiration that is well-monitored via a long timescale [39] but can ignore the replenishment of soil water in the growing season, which is important for vegetation growth across the TP. In terms of NPP, our product has greater NPP estimates for forests compared with the gauged (or MODIS-derived) NPP, and it may overestimate the NRVCU; meanwhile, the latest version of MODIS-derived NPP (v006) and more sampling sites of forest should be adopted to verify the feasibility of estimated NPP. In fact, human activities and natural mechanisms are vital factors to NPP [51]; thus, future research can consider the influences of these factors on NPP that 
could be an interesting topic. Additionally, the spatial interpolation method of solar radiation adopted the Kriging method, which could induce the indeterminacy to estimate NPP, and a machine learning algorithm should be considered in the future research. Moreover, the selected lagged effect primarily occurred in the year following the extreme drought event. A longer lagged effect on vegetation net carbon uptake and respiration should be explored for forests owing to their complicated structures and ecosystem functions. Finally, many factors could affect drought resilience, and future research should capture such information in detail.

\section{Conclusions}

In the present study, we adopted the SPEI based on meteorological data with ameliorative spatial resolution to measure drought magnitude across the TP during 1982-2015. The estimated NPP, based on a light use efficiency model (i.e., the CASA model), was employed to quantise the NRVCU, and the response of the vegetation net carbon uptake to extreme drought was investigated in different ecosystems. The SPEI spatiotemporal patterns indicated that the Qaidam Basin and most forest regions on the TP demonstrated drought trends. The improvement in the water regime and thermal conditions restrained the NRVCU on the TP during the 1982-2015 period. The concurrent and lagged effects of extreme drought on the NRVCU exhibited significant differences in the alpine steppe and alpine meadow ecosystems, but no discrepancy was found for forests, which was primarily due to their vegetation properties and environmental conditions. Forests requires a longer time period to recover their net carbon uptakes than that of alpine steppe and alpine meadow ecosystems because of their complex ecosystem structure. This study provides information regarding the lagged effect of extreme drought on the vegetation net carbon uptake on the TP. In future studies, incorporating the process mechanisms such as the lagged effect of extreme drought on the vegetation net carbon uptake may be helpful in managing net carbon fluxes.

Supplementary Materials: The following are available online at http://www.mdpi.com/2072-4292/12/15/2347/s1, Figure S1. The comparison (ME: mean error, BIAS: relative bias, NSE: Nash-Sutcliffe coefficient efficiency, RMSE: root mean square error, and $r$ : correlation coefficient) between the Global SPEI database and calculating SPEI in 1985, 1995, and 2005. Figure S2. (a)-(h) represent the temporal trends; interannual variability (IAV); and standard deviations for the net primary production (NPP), net reduction in vegetation carbon uptake (NRVCU), and Standardised Precipitation-Evapotranspiration Index (SPEI) in the (A) alpine steppe, (B) alpine meadow, and $(\mathrm{C})$ forest ecosystems. Horizontal lines in box plots denote the $95 \mathrm{th}$, 75 th, average value, 25th, and 5th percentiles from top to bottom. Figure S3. The correlation analysis between (a) monthly mean net reduction in vegetation carbon uptake (NRVCU) and monthly mean precipitation, (b) monthly mean NRVCU and monthly mean temperature, and (c) monthly mean precipitation and temperature. Figure S4. Spatial patterns of the multi-year mean for (a) precipitation, (b) temperature, and (c) relative humidity in the Tibetan Plateau during the 1982-2015 period and temporal trends of (d) precipitation, (e) temperature, and (f) relative humidity. Figure S5. Spatial correlation between (a) net reduction in vegetation carbon uptake (NRVCU) and precipitation, (b) NRVCU and temperature. The significance level between (c) NRVCU and precipitation, (d) NRVCU and temperature. Figure S6. Correlation analysis between vegetation net carbon uptake and (a) alkali-hydrolysable N, (b) available P, (c) available K, (d) cation exchange capacity, (e) soil organic matter, (f) PH, (g) soil moisture, (h) total N, and (i) total P. Figure S7. (a) Alkali-hydrolysable N, (b) available P, (c) available K, (d) cation exchange capacity, (e) soil organic matter, (f) PH, (g) soil moisture, (h) total N, and (i) total P in (A) alpine steppe, (B) alpine meadow, and (C) forest ecosystems. Horizontal lines in the box plots denote the 95th, 75th, average value, 25 th, and 5 th percentiles from top to bottom.

Author Contributions: Conceptualization, J.S. and C.Y.; methodology, C.Y.; software, C.Y.; validation, J.S. and C.Y.; formal analysis, C.Y.; investigation, C.Y.; resources, J.X.; data curation, J.S.; writing-original draft preparation, C.Y.; writing-review and editing, M.L., N.Z., J.H., A.T., Y.H., and X.D.; visualization, C.Y.; supervision, J.S.; project administration, J.S.; funding acquisition, J.S. and J.X. All authors have read and agreed to the published version of the manuscript.

Funding: This research was supported by the Second Tibetan Plateau Scientific Expedition and Research (Grant No.2019QZKK0405), the National Natural Science Foundation of China (No.41871040), and the Science and Technology Project of Xizang Autonomous Region (Grant No. XZ201901-GA-07).

Conflicts of Interest: The authors declare that they have no conflicts of interest. 


\section{References}

1. He, W.; Ju, W.; Schwalm, C.R.; Sippel, S.; Wu, X.; He, Q.; Song, L.; Zhang, C.; Li, J.; Sitch, S.; et al. Large-scale droughts responsible for dramatic reductions of terrestrial net carbon uptake over North America in 2011 and 2012. J. Geophys. Res. Biogeosci. 2018, 123, 2053-2071. [CrossRef]

2. Stocker, T.F.; Qin, D.; Plattner, G.-K.; Tignor, M.; Allen, S.K.; Boschung, J.; Nauels, A.; Xia, Y.; Bex, V.; Midgley, P.M. Climate Change 2013: The Physical Science Basis. Contribution of Working Group I to the Fifth Assessment Report of the Intergovernmental Panel on Climate Change; Cambridge University Press: Cambridge, UK; New York, NY, USA, 2013.

3. Huang, M.; Wang, X.; Keenan, T.F.; Piao, S. Drought timing influences the legacy of tree growth recovery. Glob. Chang. Biol. 2018, 24, 3546-3559. [CrossRef]

4. Frank, D.; Reichstein, M.; Bahn, M.; Thonicke, K.; Frank, D.; Mahecha, M.D.; Smith, P.; van der Velde, M.; Vicca, S.; Babst, F.; et al. Effects of climate extremes on the terrestrial carbon cycle: Concepts, processes and potential future impacts. Glob. Chang. Biol. 2015, 21, 2861-2880. [CrossRef]

5. Reichstein, M.; Bahn, M.; Ciais, P.; Frank, D.; Mahecha, M.D.; Seneviratne, S.I.; Zscheischler, J.; Beer, C.; Buchmann, N.; Frank, D.; et al. Climate extremes and the carbon cycle. Nature 2013, 500, 287-295. [CrossRef]

6. Li, X.; Li, Y.; Chen, A.; Gao, M.; Slette, I.J.; Piao, S. The impact of the 2009/2010 drought on vegetation growth and terrestrial carbon balance in Southwest China. Agric. For. Meteorol. 2019, 269, 239-248. [CrossRef]

7. Zhang, X.; Susan Moran, M.; Zhao, X.; Liu, S.; Zhou, T.; Ponce-Campos, G.E.; Liu, F. Impact of prolonged drought on rainfall use efficiency using MODIS data across China in the early 21st century. Remote Sens. Environ. 2014, 150, 188-197. [CrossRef]

8. Ivits, E.; Horion, S.; Fensholt, R.; Cherlet, M. Drought footprint on European ecosystems between 1999 and 2010 assessed by remotely sensed vegetation phenology and productivity. Glob. Chang. Biol. 2014, 20, 581-593. [CrossRef]

9. Leuzinger, S.; Zotz, G.; Asshoff, R.; Korner, C. Responses of deciduous forest trees to severe drought in Central Europe. Tree Physiol. 2005, 25, 641-650. [CrossRef]

10. Wolf, S.; Keenan, T.F.; Fisher, J.B.; Baldocchi, D.; Desai, A.; Richardson, A.D.; Scott, R.; Law, B.E.; Litvak, M.; Brunsell, N.A.; et al. Warm spring reduced carbon cycle impact of the 2012 US summer drought. Proc. Natl. Acad. Sci. USA 2016, 113, 5880-5885. [CrossRef]

11. Schwalm, C.R.; Williams, C.A.; Schaefer, K.; Baldocchi, D.; Black, T.A.; Goldstein, A.H.; Law, B.E.; Oechel, W.C.; Scott, R.L. Reduction in carbon uptake during turn of the century drought in western North America. Nat. Geosci. 2012, 5, 551-556. [CrossRef]

12. Horridge, M.; Madden, J.; Wittwer, G. The impact of the 2002-2003 drought on Australia. J. Policy Model. 2005, 27, 285-308. [CrossRef]

13. Doughty, C.E.; Metcalfe, D.B.; Girardin, C.A.J.; Amézquita, F.F.; Cabrera, D.G.; Huasco, W.H.; Silva-Espejo, J.E.; Araujo-Murakami, A.; da Costa, M.C.; Rocha, W.; et al. Drought impact on forest carbon dynamics and fluxes in Amazonia. Nature 2015, 519, 78-82. [CrossRef] [PubMed]

14. Ciais, P.; Reichstein, M.; Viovy, N.; Granier, A.; Ogée, J.; Allard, V.; Aubinet, M.; Buchmann, N.; Bernhofer, C.; Carrara, A.; et al. Europe-wide reduction in primary productivity caused by the heat and drought in 2003. Nature 2005, 437, 529-533. [CrossRef] [PubMed]

15. Van Der Molen, M.K.; Dolman, A.J.; Ciais, P.; Eglin, T.; Gobron, N.; Law, B.E.; Meir, P.; Peters, W.; Phillips, O.L.; Reichstein, M.; et al. Drought and ecosystem carbon cycling. Agric. For. Meteorol. 2011, 151, $765-773$. [CrossRef]

16. Schwalm, C.R.; Anderegg, W.R.L.; Michalak, A.M.; Fisher, J.B.; Biondi, F.; Koch, G.W.; Litvak, M.E.; Ogle, K.; Shaw, J.D.; Wolf, A.; et al. Global patterns of drought recovery. Nature 2017, 548, 202-205. [CrossRef]

17. Schwalm, C.R.; Williams, C.A.; Schaefer, K.; Arneth, A.; Bonal, D.; Buchmann, N.; Chen, J.; Law, B.E.; Lindroth, A.; Luyssaert, S. Assimilation exceeds respiration sensitivity to drought: A FLUXNET synthesis. Glob. Chang. Biol. 2010, 16, 657-670. [CrossRef]

18. Meir, P.; Metcalfe, D.B.; Costa, A.C.; Fisher, R.A. The fate of assimilated carbon during drought: Impacts on respiration in Amazon rainforests. Philos. Trans. R. Soc. B Biol. Sci. 2008, 363, 1849-1855. [CrossRef]

19. Fisher, R.A.; Williams, M.; Da Costa, A.L.; Malhi, Y.; Da Costa, R.F.; Almeida, S.; Meir, P. The response of an Eastern Amazonian rain forest to drought stress: Results and modelling analyses from a throughfall exclusion experiment. Glob. Chang. Biol. 2007, 13, 2361-2378. [CrossRef] 
20. Chaves, M.M.; Flexas, J.; Pinheiro, C. Photosynthesis under drought and salt stress: Regulation mechanisms from whole plant to cell. Ann. Bot. 2008, 103, 551-560. [CrossRef]

21. Keenan, T.; Sabate, S.; Gracia, C. The importance of mesophyll conductance in regulating forest ecosystem productivity during drought periods. Glob. Chang. Biol. 2010, 16, 1019-1034. [CrossRef]

22. McDowell, N.G.; Beerling, D.J.; Breshears, D.D.; Fisher, R.A.; Raffa, K.F.; Stitt, M. The interdependence of mechanisms underlying climate-driven vegetation mortality. Trends Ecol. Evol. 2011, 26, 523-532. [CrossRef] [PubMed]

23. Sala, A.; Woodruff, D.R.; Meinzer, F.C. Carbon dynamics in trees: Feast or famine? Tree Physiol. 2012, 32, 764-775. [CrossRef] [PubMed]

24. Keith, H.; Gorsel, E.V.; Jacobsen, K.L.; Cleugh, H.A. Dynamics of carbon exchange in a Eucalyptus forest in response to interacting disturbance factors. Agric. For. Meteorol. 2012, 153, 67-81. [CrossRef]

25. McDowell, N.; Pockman, W.T.; Allen, C.D.; Breshears, D.D.; Cobb, N.; Kolb, T.; Plaut, J.; Sperry, J.; West, A.; Williams, D.G.; et al. Mechanisms of plant survival and mortality during drought: Why do some plants survive while others succumb to drought? New Phytol. 2008, 178, 719-739. [CrossRef]

26. Camarero, J.J.; Gazol, A.; Sangüesa-Barreda, G.; Oliva, J.; Vicente-Serrano, S.M.; Gibson, D. To die or not to die: Early warnings of tree dieback in response to a severe drought. J. Ecol. 2015, 103, 44-57. [CrossRef]

27. Ogle, K.; Barber, J.J.; Barron-Gafford, G.A.; Bentley, L.P.; Young, J.M.; Huxman, T.E.; Loik, M.E.; Tissue, D.T.; Cleland, E. Quantifying ecological memory in plant and ecosystem processes. Ecol. Lett. 2015, 18, 221-235. [CrossRef]

28. Virlouvet, L.; Fromm, M. Physiological and transcriptional memory in guard cells during repetitive dehydration stress. New Phytol. 2015, 205, 596-607. [CrossRef]

29. Anderegg, W.R.L.; Plavcová, L.; Anderegg, L.D.L.; Hacke, U.G.; Berry, J.A.; Field, C.B. Drought's legacy: Multiyear hydraulic deterioration underlies widespread aspen forest die-off and portends increased future risk. Glob. Chang. Biol. 2013, 19, 1188-1196. [CrossRef]

30. Walter, J.; Jentsch, A.; Beierkuhnlein, C.; Kreyling, J. Ecological stress memory and cross stress tolerance in plants in the face of climate extremes. Environ. Exp. Bot. 2013, 94, 3-8. [CrossRef]

31. Diez, J.M.; D’Antonio, C.M.; Dukes, J.S.; Grosholz, E.D.; Olden, J.D.; Sorte, C.J.B.; Blumenthal, D.M.; Bradley, B.A.; Early, R.; Ibáñez, I.; et al. Will extreme climatic events facilitate biological invasions? Front. Ecol. Environ. 2012, 10, 249-257. [CrossRef]

32. Zeiter, M.; Sch€arrer, S.; Zweifel, R.; Newbery, D.M.; Stampfli, A.; Ejrnaes, R. Timing of extreme drought modifies reproductive output in semi-natural grassland. J. Veg. Sci. 2016, 27, 238-248. [CrossRef]

33. Nguyen, H.; Wheeler, M.C.; Otkin, J.A.; Cowan, T.; Frost, A.; Stone, R. Using the evaporative stress index to monitor flash drought in Australia. Environ. Res. Lett. 2019, 14, 064016. [CrossRef]

34. Tsakiris, G.; Vangelis, H. Establishing a drought index incorporating evapotranspiration. Eur. Water 2005, 9 , 3-11.

35. Hobbins, M.T.; Wood, A.; McEvoy, D.J.; Huntington, J.L.; Morton, C.; Anderson, M.; Hain, C. The Evaporative Demand Drought Index. Part I: Linking Drought Evolution to Variations in Evaporative Demand. J. Hydrometeorol. 2016, 17, 1745-1761. [CrossRef]

36. Javadian, M.; Behrangi, A.; Smith, W.K.; Fisher, J.B. Global trends in evapotranspiration dominated by increases across large cropland regions. Remote Sens. 2020, 12, 1221. [CrossRef]

37. Ogunrinde, A.T.; Oguntunde, P.G.; Olasehinde, D.A.; Fasinmirin, J.T.; Akinwumiju, A.S. Drought spatiotemporal characterization using self-calibrating Palmer drought severity index in the Northern Region of Nigeria. Results Eng. 2019, 5, 1-14. [CrossRef]

38. Lu, J.; Jia, L.; Menenti, M.; Yan, Y.; Zheng, C.; Zhou, J. Performance of the standardized precipitation index based on the TMPA and CMORPH precipitation products for drought monitoring in China. IEEE J. Sel. Top. Appl. Earth Obs. Remote Sens. 2018, 11, 1387-1396. [CrossRef]

39. Vicente-Serrano, S.M.; Beguería, S.; López-Moreno, J.I. A multiscalar drought index sensitive to Global warming: The standardized precipitation evapotranspiration index. J. Clim. 2010, 23, 1696-1718. [CrossRef]

40. Guo, H.; Bao, A.; Liu, T.; Ndayisaba, F.; Jiang, L.; Zheng, G.; Chen, T.; De Maeyer, P. Determining variable weights for an Optimal Scaled Drought Condition Index (OSDCI): Evaluation in Central Asia. Remote Sens. Environ. 2019, 231, 111220. [CrossRef]

41. Xiong, J.; Yong, Z.; Wang, Z.; Cheng, W.; Li, Y.; Zhang, H.; Ye, C.; Yang, Y. Spatial and temporal patterns of the extreme precipitation across the Tibetan Plateau (1986-2015). Water 2019, 11, 1453. [CrossRef] 
42. Chen, X.; An, S.; Inouye, D.W.; Schwartz, M.D. Temperature and snowfall trigger alpine vegetation green-up on the world's roof. Glob. Chang. Biol. 2015, 21, 3635-3646. [CrossRef]

43. Tang, W.; Yang, K.; Qin, J.; Min, M. Development of a 50-year daily surface solar radiation dataset over China. Sci. China Earth Sci. 2012, 56, 1555-1565. [CrossRef]

44. Yang, K.; He, J.; Tang, W.; Qin, J.; Cheng, C.C.K. On downward shortwave and longwave radiations over high altitude regions: Observation and modeling in the Tibetan Plateau. Agric. For. Meteorol. 2010, 150, 38-46. [CrossRef]

45. Gonsamo, A.; Chen, J.M.; Ooi, Y.W. Peak season plant activity shift towards spring is reflected by increasing carbon uptake by extratropical ecosystems. Glob. Chang. Biol. 2018, 24, 2117-2128. [CrossRef]

46. Masud, M.B.; Khaliq, M.N.; Wheater, H.S. Analysis of meteorological droughts for the Saskatchewan River Basin using univariate and bivariate approaches. J. Hydrol. 2015, 522, 452-466. [CrossRef]

47. Yan, N.; Wu, B.; Chang, S.; Bao, X. Evaluation of TRMM Precipitation Product for Meteorological Drought Monitoring in Hai Basin. IOP Conf. Ser. Earth Environ. Sci. 2014, 17, 012093. [CrossRef]

48. Thornthwaite, C.W. An approach toward a rational classification of climate. Geogr. Rev. 1948, 38, 57-94. [CrossRef]

49. Gao, Q.; Li, Y.; Wan, Y.; Qin, X.; Jiangcun, W.; Liu, Y. Dynamics of alpine grassland NPP and its response to climate change in Northern Tibet. Clim. Chang. 2009, 97, 515-528. [CrossRef]

50. Gao, Q.; Wan, Y.; Li, Y.; Guo, Y.; Ganjurjav; Qin, X.; Jiangcun, W.; Wang, B. Effects of topography and human activity on the net primary productivity (NPP) of alpine grassland in northern Tibet from 1981 to 2004. Int. J. Remote Sens. 2012, 34, 2057-2069. [CrossRef]

51. Yan, Y.; Liu, X.; Wang, F.; Li, X.; Ou, J.; Wen, Y.; Liang, X. Assessing the impacts of urban sprawl on net primary productivity using fusion of Landsat and MODIS data. Sci. Total Environ. 2018, 613, 1417-1429. [CrossRef]

52. Zhu, W.; Pan, Y.; Long, Z.; Chen, Y.; Li, J.; Hu, H. Estimating net primary productivity of terrestrial vegetation based on GIS and RS: A case study in Inner Mongolia, China. J. Remote Sens. 2005, 9, 300-307.

53. Piao, S.; Fang, J.; He, J.; Xiao, Y. Spatial distribution of grassland biomass in China. Acta Phytoecol. Sin. 2004, 28, 491-498.

54. Liu, J.; Meng, B.; Ge, J.; Gao, J.; Yin, J.; Hou, M.; Feng, Q.; Liang, T. Spatio-temporal dynamic changes of grassland NPP in Gannan prefecture, as determined by the CASA model. Acta Prataculturae Sin. 2019, 28, 19-32.

55. Yang, Y.C.; Cheng, G.W.; Fan, J.H.; Li, W.P.; Sun, J.; Sha, Y.K. Validation study of TMPA 3B42V6 in a typical alpine and gorge region: Jinsha River basin, China. Nat. Hazards Earth Syst. Sci. 2013, 13, 3479-3492. [CrossRef]

56. Gang, C.; Zhou, W.; Chen, Y.; Wang, Z.; Sun, Z.; Li, J.; Qi, J.; Odeh, I. Quantitative assessment of the contributions of climate change and human activities on global grassland degradation. Environ. Earth Sci. 2014, 72, 4273-4282. [CrossRef]

57. Anav, A.; Friedlingstein, P.; Beer, C.; Ciais, P.; Harper, A.; Jones, C.; Murray-Tortarolo, G.; Papale, D.; Parazoo, N.C.; Peylin, P.; et al. Spatiotemporal patterns of terrestrial gross primary production: A review. Rev. Geophys. 2015, 53, 785-818. [CrossRef]

58. Ahlstrom, A.; Raupach, M.R.; Schurgers, G.; Smith, B.; Arneth, A.; Jung, M.; Reichstein, M.; Canadell, J.G.; Friedlingstein, P.; Jain, A.K.; et al. The dominant role of semi-arid ecosystems in the trend and variability of the land $\mathrm{CO}_{2}$ sink. Science 2015, 348, 895-899. [CrossRef] [PubMed]

59. Yao, Y.; Wang, X.; Li, Y.; Wang, T.; Shen, M.; Du, M.; He, H.; Li, Y.; Luo, W.; Ma, M.; et al. Spatiotemporal pattern of gross primary productivity and its covariation with climate in China over the last thirty years. Glob. Chang. Biol. 2018, 24, 184-196. [CrossRef]

60. Sun, J.; Zhou, T.; Liu, M.; Chen, Y.; Liu, G.; Xu, M.; Shi, P.; Peng, F.; Tsunekawa, A.; Liu, Y.; et al. Water and heat availability are drivers of the aboveground plant carbon accumulation rate in alpine grasslands on the Tibetan Plateau. Glob. Ecol. Biogeogr. 2019, 29, 50-64. [CrossRef]

61. Niu, S.; Wu, M.; Han, Y.; Xia, J.; Li, L.; Wan, S. Water-mediated responses of ecosystem carbon fluxes to climatic change in a temperate steppe. New Phytol. 2008, 177, 209-219. [CrossRef]

62. Melillo, J.M.; Steudler, P.A.; Aber, J.D.; Newkirk, K.; Lux, H.; Bowles, F.P.; Catricala, C.; Magill, A.; Ahrens, T.; Morrisseau, S. Soil warming and carbon-cycle feedbacks to the climate system. Science 2002, 298, 2173-2176. [CrossRef] [PubMed] 
63. Wan, S.; Hui, D.; Wallace, L.; Luo, Y. Direct and indirect effects of experimental warming on ecosystem carbon processes in a tallgrass prairie. Glob. Biogeochem. Cycles 2005, 19,1-13. [CrossRef]

64. Patrick, L.; Cable, J.; Potts, D.; Ignace, D.; Barron-Gafford, G.; Griffith, A.; Alpert, H.; Van Gestel, N.; Robertson, T.; Huxman, T.E.; et al. Effects of an increase in summer precipitation on leaf, soil, and ecosystem fluxes of CO2 and H2O in a sotol grassland in Big Bend National Park, Texas. Oecologia 2007, 151, 704-718. [CrossRef] [PubMed]

65. Davidson, E.A.; Janssens, I.A. Temperature sensitivity of soil carbon decomposition and feedbacks to climate change. Nature 2006, 440, 165-173. [CrossRef] [PubMed]

66. Kim, D.G.; Vargas, R.; Bond-Lamberty, B.; Turetsky, M.R. Effects of soil rewetting and thawing on soil gas fluxes: A review of current literature and suggestions for future research. Biogeosciences 2012, 9, 2459-2483. [CrossRef]

67. Vicca, S.; Bahn, M.; Estiarte, M.; van Loon, E.E.; Vargas, R.; Alberti, G.; Ambus, P.; Arain, M.A.; Beier, C.; Bentley, L.P.; et al. Can current moisture responses predict soil $\mathrm{CO}_{2}$ efflux under altered precipitation regimes? A synthesis of manipulation experiments. Biogeosciences 2014, 11, 2991-3013. [CrossRef]

68. Piao, S.; Friedlingstein, P.; Ciais, P.; Viovy, N.; Demarty, J. Growing season extension and its impact on terrestrial carbon cycle in the Northern Hemisphere over the past 2 decades. Glob. Biogeochem. Cycles 2007, 21, 1-11. [CrossRef]

69. Xu, Z.X.; Gong, T.L.; Li, J.Y. Decadal trend of climate in the Tibetan Plateau-Regional temperature and precipitation. Hydrol. Process. 2008, 22, 3056-3065. [CrossRef]

70. Wang, X.; Wang, T.; Liu, D.; Zhang, T.; Xu, J.; Cui, G.; Lv, G.; Huang, H. Multisatellite analyses of spatiotemporal variability in photosynthetic activity over the Tibetan Plateau. J. Geophys. Res. Biogeosci. 2019, 124, 3778-3797. [CrossRef]

71. Jiang, Y.; Wang, P.; Xu, X.; Zhang, J. Dynamics of carbon fluxes with responses to vegetation, meteorological and terrain factors in the south-eastern Tibetan Plateau. Environ. Earth Sci. 2014, 72, 4551-4565. [CrossRef]

72. Pan, H.; Li, M.; Gai, X.; Wu, J.; Du, Z.; Liu, X. Responses of growth and ecophsiology of plants to altitude. Ecol. Environ. Sci. 2009, 18, 722-730.

73. Wright, I.J.; Reich, P.B.; Cornelissen, J.H.C.; Falster, D.S.; Groom, P.K.; Hikosaka, K.; Lee, W.; Lusk, C.H.; Niinemets, Ü.; Oleksyn, J.; et al. Modulation of leaf economic traits and trait relationships by climate. Glob. Ecol. Biogeogr. 2005, 14, 411-421. [CrossRef]

74. Yang, Y.; Yao, Y.; Zhang, X. Comparison of growth and physiological responses to severe drought between two altitudinal Hippophae rhamnoides populations. Silva. Fenn. 2010, 44, 603-614. [CrossRef]

75. Stampfli, A.; Bloor, J.M.G.; Fischer, M.; Zeiter, M. High land-use intensity exacerbates shifts in grassland vegetation composition after severe experimental drought. Glob. Chang. Biol. 2018, 24, 2021-2034. [CrossRef] [PubMed]

76. Stuart-Haëntjens, E.; De Boeck, H.J.; Lemoine, N.P.; Mänd, P.; Kröel-Dulay, G.; Schmidt, I.K.; Jentsch, A.; Stampfli, A.; Anderegg, W.R.L.; Bahn, M.; et al. Mean annual precipitation predicts primary production resistance and resilience to extreme drought. Sci. Total Environ. 2018, 636, 360-366. [CrossRef] [PubMed]

77. Ponce-Campos, G.E.; Moran, M.S.; Huete, A.; Zhang, Y.; Bresloff, C.; Huxman, T.E.; Eamus, D.; Bosch, D.D.; Buda, A.R.; Gunter, S.A.; et al. Ecosystem resilience despite large-scale altered hydroclimatic conditions. Nature 2013, 494, 349-352. [CrossRef]

78. Fracasso, A.; Trindade, L.; Amaducci, S. Drought tolerance strategies highlighted by two Sorghum bicolor races in a dry-down experiment. J. Plant. Physiol. 2016, 190, 1-14. [CrossRef]

79. Zhang, L.; Wang, S.; Liu, S.; Liu, X.; Zou, J.; Siemann, E. Perennial forb invasions alter greenhouse gas balance between ecosystem and atmosphere in an annual grassland in China. Sci. Total Environ. 2018, 642, 781-788. [CrossRef]

80. Fischer, R.; Knapp, N.; Bohn, F.; Shugart, H.H.; Huth, A. The Relevance of Forest Structure for Biomass and Productivity in Temperate Forests: New Perspectives for Remote Sensing. Surv. Geophys 2019, 40, 709-734. [CrossRef]

81. Teuling, A.J.; Seneviratne, S.I.; Stöckli, R.; Reichstein, M.; Moors, E.; Ciais, P.; Luyssaert, S.; van den Hurk, B.; Ammann, C.; Bernhofer, C.; et al. Contrasting response of European forest and grassland energy exchange to heatwaves. Nat. Geosci. 2010, 3, 722-727. [CrossRef] 
82. Anderegg, W.R.; Schwalm, C.; Biondi, F.; Camarero, J.J.; Koch, G.; Litvak, M.; Ogle, K.; Shaw, J.D.; Shevliakova, E.; Williams, A.P.; et al. Pervasive drought legacies in forest ecosystems and their implications for carbon cycle models. Science 2015, 349, 528-532. [CrossRef] [PubMed]

83. Gessler, A.; Schaub, M.; McDowell, N.G. The role of nutrients in drought-induced tree mortality and recovery. New Phytol. 2017, 214, 513-520. [CrossRef] [PubMed]

84. Ganjurjav, H.; Gao, Q.; Gornish, E.S.; Schwartz, M.W.; Liang, Y.; Cao, X.; Zhang, W.; Zhang, Y.; Li, W.; Wan, Y.; et al. Differential response of alpine steppe and alpine meadow to climate warming in the central Qinghai-Tibetan Plateau. Agric. For. Meteorol. 2016, 223, 233-240. [CrossRef]

85. AghaKouchak, A.; Farahmand, A.; Melton, F.S.; Teixeira, J.; Anderson, M.C.; Wardlow, B.D.; Hain, C.R. Remote sensing of drought: Progress, challenges and opportunities. Rev. Geophys. 2015, 53, 452-480. [CrossRef]

86. Andreadis, K.M.; Clark, E.A.; Wood, A.W.; Hamlet, A.F.; Lettenmaier, D.P. Twentieth-Century drought in the Conterminous United States. J. Hydrometeorol. 2005, 6, 985-1001. [CrossRef]

87. Gang, C.; Zhao, W.; Zhao, T.; Zhang, Y.; Gao, X.; Wen, Z. The impacts of land conversion and management measures on the grassland net primary productivity over the Loess Plateau, Northern China. Sci. Total Environ. 2018, 645, 827-836. [CrossRef]

(C) 2020 by the authors. Licensee MDPI, Basel, Switzerland. This article is an open access article distributed under the terms and conditions of the Creative Commons Attribution (CC BY) license (http://creativecommons.org/licenses/by/4.0/). 